Veronica Brito da Silva'+, Rogerio Figueiredo Daher', Bruna Rafaela da Silva Menezes', Maria Lorraine Fonseca Oliveira', Maria do Socorro Bezerra Araújo', Antonio Alonso Cecon Novo'

\title{
DIFFERENT STABILITY METHODS FOR CULTIVAR RECOMMENDATION IN ELEPHANT-GRASS FOR ENERGY PURPOSES IN BRAZIL
}

Keywords:

Alternative energy

Biomass

Genotype

Cutting interaction

Historic:

Received 29/12/2016

Accepted I I/12/2017

Palavras chave:

Energia alternativa

Biomassa

Genótipo

Corte

${ }^{+}$Correspondence: verabritosl@hotmail.com
ABSTRACT: The elephant-grass undergoes successive cutting and periodical evaluations that it possible to identify clones with high stability for dry matter production, which can be used for energy production. The present study was carried out to evaluate stability dry matter yield for different parametric and non-parametric methods in elephant grass genotypes for biomass production undergoes successive cutting in the agroclimatic conditions of the Norte Fluminense (RJ, Brazil). The variable measured in the 40 genotypes was dry matter yield (DMY) at 2009, 2010 and $201 \mathrm{I}$ in a field study designed as randomized block design with two replicates. Each sample was grown in different environment condition. The stability methods tested were the Yates and Cochran's, Plaisted and Peterson's, Wricke's ecovalence, Annicchiarico's, Lin and Binns' and Kang and Phan's. Results indicated that cutting $(E)$ and genotypes $(G)$ influenced significantly on the performance of dry matter yield. The non-parametric stability methods were effective for the evaluation of stability in dry matter yield. Genotypes Mercker, Pinda-México, Mercker 86-México, Guaçu/IZ, Mercker Pinda, P-24I-Piracicaba and Cubano Pinda were stable stability dry matter yield. Hence, there are genotypes may be exploited in future breeding programmes in order to improve productivity of upland elephant grass over environment.

\section{MÉTODOS DE ESTABILIDADE DIFERENTES PARA RECOMENDAÇÃO DE CULTIVAR EM CAPIM ELEFANTE PARA FINS DE ENERGIA NO BRASIL}

RESUMO: O capim-elefante sofre sucessivos cortes em avaliações periódicas, possibilitando identificar clones com alta estabilidade para a produção de matéria seca, podendo ser utilizados para a produção de energia. O presente estudo foi realizado para avaliar a estabilidade na produção de matéria seca, considerando métodos paramétricos e não paramétricos, em genótipos de capim-elefante para produção de biomassa submetido a cortes sucessivos nas condições climáticas do Norte Fluminense (RJ, Brasil). A variável medida nos 40 genótipos foi a produção de matéria seca (DMY) em 2009, 2010 e 201 I em um experimento de campo em blocos casualizados com duas repetições. Cada amostra foi cultivada em diferentes condições ambientais. Os métodos de estabilidade testados foram de Yates e Cochran, Plaisted e Peterson, Wricke, Annicchiarico, Lin e Binns e Kang e Phan. Os resultados indicaram que o corte (E) e os genótipos (G) influenciaram significativamente no desempenho para a produção de matéria seca. Os métodos de estabilidade não-paramétrica foram eficientes para a avaliação da estabilidade no rendimento da matéria seca. Os genótipos Mercker, Pinda-México, Mercker 86-México, Guaçu/IZ, Mercker Pinda, P-24I-Piracicaba e Cubano Pinda tiveram uma estabilidade estável na produção de materia seca. Por conseguinte, existem genótipos que podem ser explorados em futuros programas de melhoramento, a fim de melhorar a produtividade de capim elefante no ambiente. 


\section{INTRODUCTION}

Elephant grass (Pennisetum purpureum Schum.) is a tropical perennial grass with high production of biomass. Because of its broad genetic variability, this grass is able to adapt to climatic conditions prevailing in almost the entire Brazil (ANDERSON et al. 2008; OLIVEIRA et al., 2013; DAHER at al. 2014; OLIVEIRA et al. 20I4; ROSSI et al., 20I4; SANTOS et al., 20I4a,b; MENEZES et al. 2015; OLIVEIRA et al., 2015). However, it is considered a species of high photosynthetic efficiency. This results in a great dry-matter-accumulation capacity and a high percentage of fiber, which is important for energy production (JAKOB et al., 2009; LEE et al., 2010; SOMERVILLE et al., 2010; KALT et al., 20I ; AZEVEDO et al., 20I2). With the ever-increasing importance of this forage in Brazil, a trait that should be taken into account is the production stability of genotypes, which can be used to select materials that adapt better to different environmental conditions to provide higher yields and reduce the costs with the culture (DAHER et al. 2003; CUNHA et al. 2013; ROCHA et al. 20I5).

The significant effect of the genotype $\times$ environment interaction indicates inconsistent performance of the genotypes according to the environmental variables. The evaluation of this interaction is essential for plant breeding, because the best genotype in a certain environment may not have the same response in another, so it would be necessary to evaluate the stability of the genotypes (ESCOBAR et al.; 20I I, CASTILLO et al., 20I2; BOSE et al., 20I4; SINGH et al., 20I4). According to Cruz and Carneiro (2014) prefer to use the term stability when referring to the response of cultivars over the years in a certain location (temporal stability). When environments are made up of different locations, in a given year it is preferable to use the term adaptability (geographic stability). In an experiment in which successive cuts and evaluations of cultivars are performed over time, it is possible to estimate the temporal stability, which is the greatest interest of producers - an essential factor to guide genetic breeding studies (CUNHA et al., 2013; NASCIMENTO et al., 20I3; ROCHA et al., 20I5).

There are methods for stability analysis in several environments, and these methods differ in the stability concepts and principles. Among the proposed methods for study and quantification of the genotype $X$ environment interaction, procedures based on Yates and Cochran's , Plaisted and Peterson's, and Wricke's parametrics methods and Annicchiarico's , Lin and Binns' and Kang and Phan's non-parametric methods (CRUZ and CARNEIRO,
2014; ROCHA et al. 2015). Thus, the objective of the present study was carried out to evaluate stability dry matter yield and to compare different parametric and nonparametric stability methods in elephant grass genotypes for biomass production undergoes successive cuttings in Norte Fluminense region, RJ, Brazil.

\section{MATERIALS AND METHODS}

Forty elephant grass genotypes were evaluated during 2008-20II seasons at one location (Colégio Estadual Agrícola Antônio Sarlo Research Farm), Campos dos Goytacazes/RJ, Brazil ( $321^{\circ} 45^{\prime} \mathrm{S}, 41^{\circ} 20^{\prime} \mathrm{W}$, and II $\mathrm{m}$ asl) . The randomized complete blocks design with two replications. The experimental plot consisted of one rows $1.5 \mathrm{~cm}$ apart and $3 \mathrm{~m}$ in length. Fertilizers were applied at $100 \mathrm{~kg} \cdot \mathrm{ha}^{-1} \mathrm{P}_{2} \mathrm{O}_{5}$ (single superphosphate) prior to sowing and $25 \mathrm{~kg} \cdot \mathrm{ha}^{-1}$ of $\mathrm{N}$ (ammonium sulfate) and $25 \mathrm{~kg} \cdot \mathrm{ha}^{-1}$ of $\mathrm{K}_{2} \mathrm{O}$ (potassium chloride) in shooting stage in four years. The crop was irrigated as needed and weeds were manually controlled.

Dry matter yield (DMY) was measured based on each plot performance. Afterwards, the plants were cut for evaluation in four occasions: the first in June 2009 ( 12 months after planting), the second in April 2010 ( 10 months after first cutting), the third in February 20II (10 months after second cutting), and the fourth in August 20I I (six months third cutting). The code number and origin of the studied genotypes are presented in Table I.

\section{Statistical analysis}

The combined-analysis model [I]employed was the following, (STEEL et al., 1996), where $Y_{i j k}$ is the observed value of the-th genotype on the $j$-th block within the $k$-th cutting; $m$ is the overall mean of the trial; $P_{i}$ is the effect of the $i$-th genotype; $B_{j}$ is the effect of the $j$-th block; $\varepsilon_{i j}$ is the error associated with the interaction between genotype $i$ and block $j ; S_{k}$ is the effect of the $k$-th cutingt; $\varepsilon_{\mathrm{jk}}$ is the error associated with the interaction between block $j$ and cutting $k ; P S_{i k}$ is the effect of the interaction between treatment $i$ and cutingt $k ; \varepsilon_{\mathrm{ijk}}$ is the error associated with the interaction among treatment $i$, block $j$, and cutting $k$.

$$
Y_{i j k}=m+P_{i}+B_{j}+\varepsilon_{i j}+S_{k}+\varepsilon_{j k}+P S_{i k}+\varepsilon_{i j k}
$$

Stability methods were employed due to the significant genotypes and cutting interaction, Yates and Cochran's, Plaisted and Peterson's, Wricke's parametrics methods and Lin and Binns', Kang and Phan', Annicchiarico's non-parametric methods the procedure described by Cruz and Carneiro (20l4), considering 
TABLE I Genotypes (40) of elephant grass from the Active Germplasm Bank of elephant grass at Universidade Estadual do Norte Fluminense.

\begin{tabular}{|c|c|c|}
\hline Identification & Genotypes & Origin \\
\hline 1 & Elefante de Colômbia & Colombia \\
\hline 2 & Mercker & Brazil \\
\hline 3 & Três Rios & Brazil \\
\hline 4 & Mercker Santa Rita & Brazil \\
\hline 5 & Pusa Napier $n^{\circ} 2$ & India \\
\hline 6 & Gigante de Pinda & Brazil \\
\hline 7 & Napier $n^{\circ} 2$ & Brazil \\
\hline 8 & Mercker S.E.A. & Brazil \\
\hline 9 & Taiwan A-I48 & Brazil \\
\hline 10 & Porto Rico 534-B & Brazil \\
\hline II & Albano & Colombia \\
\hline 12 & Híbrido Gigante da Colômbia & Colombia \\
\hline 13 & Pusa Gigante Napier & India \\
\hline 14 & Costa Rica & Costa Rica \\
\hline 15 & Cubano Pinda & Brazil \\
\hline 16 & Mercker Pinda & Brazil \\
\hline 17 & MerckerPinda México & Mexico \\
\hline 18 & Mercker 86 - México & Mexico \\
\hline 19 & Taiwan A-I44 & Brazil \\
\hline 20 & Napier S.E.A. & Brazil \\
\hline 21 & Taiwan A-I43 & Brazil \\
\hline 22 & Elefante de Pinda & Colombia \\
\hline 23 & Mineiro & Brazil \\
\hline 24 & Mole de Volta Grande & Brazil \\
\hline 25 & Napier & Brazil \\
\hline 26 & Teresópolis & Brazil \\
\hline 27 & Taiwan A-46 & Brazil \\
\hline 28 & Duro de Volta Grande & Brazil \\
\hline 29 & Merckeron Comum Pinda & Brazil \\
\hline 30 & Cameroon- Piracicaba & Brazil \\
\hline 31 & Taiwan A-I2I & Brazil \\
\hline 32 & P-24I-Piracicaba & Brazil \\
\hline 33 & IAC - Campinas & Brazil \\
\hline 34 & Elefante de Cachoeiro de Itapemirim & Brazil \\
\hline 35 & Roxo & Brazil \\
\hline 36 & Guaçu/IZ.2 & Brazil \\
\hline 37 & King Grass & Brazil \\
\hline 38 & Roxo Botucatu & Brazil \\
\hline 39 & Vruckwona Africana & Africa \\
\hline 40 & Pasto Panama & Panama \\
\hline
\end{tabular}

the successive cuts as environments of evaluation of genotypes. Spearman's coefficient $(\rho)$ was used in order to evaluate the degree of concordance among the employed methods.

\section{Yates and Cochran's (traditional) method}

This method consists of a combined analysis of all environments and the subsequent deployment of the squares sum of the environmental effects and of the genotypes $\times$ environment interaction into effects of environments within each genotype. The genotypes that show the lowest $\theta i$ values are the most stable. Its stability estimator is the following [2], where $Y_{i j}$ is the mean of genotype $i(i=1,2, \ldots, g)$ in environment $j(j=1,2, \ldots, a)$; and $r$ is the number of replicates associated with the genotype.

$Q M\left(\frac{A}{G_{i}}\right)=\left(\frac{r}{(\alpha-1)}\right)\left[\sum_{i}\left(Y_{(i j)}\right)^{2}-\frac{\left(Y_{i}\right)^{2}}{\alpha}\right]$

\section{Plaisted and Peterson's method}

The estimator of the stability $\left(\theta_{\mathrm{i}}\right)$ is the arithmetic mean of the variance components of the interaction between pairs of genotypes and environments $\left(\sigma_{g a}^{2}\right)$ that involves a certain specific genotype. Its estimate was obtained by the following [3], [4], [5] and [6].

$$
\begin{aligned}
& \frac{\sum_{i^{\prime}} \sigma_{g a_{i^{\prime}}}^{2} \text { in which } i=i^{\prime}}{g-1} \\
& \sigma_{g a_{u}}^{2}=\frac{\frac{\operatorname{SQ}_{\left(G_{i \prime} \times A\right)}}{a-1} \text { QMR }}{r}
\end{aligned}
$$

$S Q_{\left(G_{i i} \times A\right)}^{\prime}=\frac{r}{2}\left[d_{i i}^{2}-\frac{1}{a}\left(Y_{i}-Y_{i}^{\prime}\right)^{2}\right]$

$d_{i i}^{2}=j\left(Y_{i j}-Y_{\left.\left(i^{\prime} j\right)\right)^{2}}(\right.$ for $\mathrm{j}=1,2, \ldots, \mathrm{a})$

The relative contribution of each genotype was calculated as presented in [7]

$\theta_{i}(\%)=\frac{\theta_{i} \times 100}{g \sigma_{g a}^{2}}$

\section{Wricke's method}

The ecovalence $(\omega i)$ or stability of genotype $i$ is given by, where: $\bar{Y}_{i j}$ : mean of genotype $i$ in environment $j ; \bar{Y}_{i}$ : mean of genotype $i ; \bar{Y}_{j}$ : mean of environment $j$; and $\bar{Y}$ : overall mean. Thus, genotypes with low $\omega i$ values have lower deviations in relation to the environments and are more stable

$$
\omega_{i}=r \sum_{j}\left(\bar{Y}_{i j}-\bar{Y}_{i}-\bar{Y}_{j}+\bar{Y}_{. .}\right)^{2}
$$

\section{Annicchiarico's method}

Annicchiarico's method [9] is based on the genotypic confidence index, estimated by, considering all environments, where $\mu_{\mathrm{i}(\mathrm{g})}$ is the mean percentage of clones $i ; \sigma_{z_{i}(g)}$ is the standard deviation from values $Z_{i j}$, associated with the $i$-th genotype; $z_{(I-\alpha)}$ is the percentage of the standard normal distribution function. The adopted confidence coefficient was $75 \%$, i.e., $\alpha=0.25$. 
$I_{i(g)}=\mu_{i(g)}-z_{(I-a)} \sigma_{z i(g)}$

\section{Lin and Binns' method}

In this method, the parameter $\mathrm{Pi}$ [10] defines the stability of a genotype and is defined as the meansquared distance among the mean of a genotype and the mean maximum response for all sites, such that genotypes with lower values correspond to those of better performance. Thus, the estimator is given, Where: $P_{i}=$ superiority index of the $i$-th genotype; $X_{i j}=$ yield of the $i$-th genotype in the $j$-th location; $M_{j}=$ maximum response obtained in all clones in the $j$-th location; and $n=$ number of locations. Next, the expression was decomposed to obtain the genetic deviation and the deviation due to the interaction. The genetic deviation [II] was obtained by the following expression, where: $Y_{i}$ is the mean of genotype I [12]; and $\bar{M}$ is the mean of clones with maximum response [13].

$$
\begin{aligned}
& P_{i}=\frac{\sum_{j=1}^{n}\left(X_{i j}-M_{j}\right)^{2}}{2 n} \\
& \sum_{j=1}^{n} \frac{\left(Y_{i j}-\bar{Y}_{i}-M_{j}+\bar{M}\right)^{2}}{2 n} \\
& Y_{i}=\frac{\sum_{j=1}^{n} Y_{i j}}{n} \\
& \bar{M}=\frac{\sum_{j=1}^{n} M_{j}}{n}
\end{aligned}
$$

\section{RESULTS AND DISCUSSION}

Significant differences were observed by the $F$ test $(P<0.05)$ and $(P<0.01)$ for dry matter yield in all cuts. The average biomass production decreased from $36.96 \mathrm{t} \cdot \mathrm{ha}^{-1}$ (3rd cut) to II.38 t.ha-1 (4th cut) (Table 2) due to the shorter cutting interval. Daher et al., (2003), evaluated genotypes of elephant grass aiming at stability in forage production and found variation in the means per cut, which ranged from $0.755 \mathrm{t} \cdot \mathrm{ha}^{-1}$ to $8.453 \mathrm{t} \cdot \mathrm{ha}^{-1}$.

For dry matter yield, the lowest experimental coefficient of variation was $21.41 \%$ ( 3 rd cut), and the highest was 29.47\% (2nd cut). Cunha et al. (2013) evaluated eight genotypes of Pennisetum spp. for forage production and obtained coefficients of variation varying from $40.3 \%$ to $33.7 \%$.

TABLE 2 Analysis variances individual of dry matter yield $\left(\mathrm{t} / \mathrm{ha}^{-1}\right)$ of 40 genotypes of elephant grass.

\begin{tabular}{cccccc}
\hline \multirow{2}{*}{$\begin{array}{c}\text { Source of } \\
\text { variance }\end{array}$} & \multicolumn{5}{c}{ Mean Squared } \\
\cline { 2 - 6 } & ${ }^{\mathrm{D} D F}$ & Cutting & Cutting & Cutting $_{3}$ & Cutting \\
\hline Block & $\mathrm{I}$ & 121.43 & 298.34 & 7.5 & 39.4 \\
Genotype & 39 & $68.55^{*} *$ & $58.75 *$ & $26.9 * *$ & $15.62^{*}$ \\
Residue & 39 & 30.8 & 33.02 & 7.28 & 9.1 \\
Mean & & 20.55 & 19.49 & 36.96 & 11.38 \\
${ }^{\mathrm{b}} \mathrm{CV}(\%)$ & & 27.00 & 29.47 & 21.41 & 26.49 \\
\hline
\end{tabular}

**significant at $1 \%$ probability; * significant at $5 \%$ probability. ${ }^{a}$ Degrees of freedom. ${ }^{b}$ coefficient of variation.
The values obtained in the individual analyses of variance (per cut) of dry matter yield in $\mathrm{t} \cdot \mathrm{ha}^{-1}$ resulted in a relationship between the highest and lowest residual mean square (RMS) of 4.53 , indicating a relative homogeneity of variances, which allowed the use of these cuts in the combined analysis of variance. Daher et al. (2003) evaluated elephant-grass cultivars to estimate stability parameters and obtained the proportion of 4.94 between the highest and lowest RMS value for the studied cuts.

Based on the combined analysis of variance, the genotypes differed from each other, which indicates the presence of genetic variability. They also showed significant differences by the $F$ test $(P<0.05)$ for the sources of variation cut and genotypes $\times$ cuts interaction, which proves that the genotypes' responses were not the same in all cuts (Table 3). According, Rocha et al. (20I5) evaluated elephant-grass in the biannual cuts, combined variance analysis demonstrated significant effects of cuts, genotypes, and cut $\times$ genotype interaction on dry matter yield, indicating that the genotypes had different performances.

TABLE 3 Combined variance analysis of dry matter yield ( $t$ / $\mathrm{ha}^{-1}$ ) of 40 genotypes of elephant grass.

\begin{tabular}{ccc}
\hline Source of variation & ${ }^{\mathrm{D}} \mathrm{DF}$ & Mean Square \\
\hline Block/Cut & $\mathrm{I}$ & $746.0 \mathrm{I}$ \\
Genotype & 39 & $157.36^{*}$ \\
Error A & 39 & 52.62 \\
Cut & 3 & $9196.5 \mathrm{I}^{* *}$ \\
Error B & 3 & 38.48 \\
Genotype $\times$ Cut & 117 & $60.68^{* *}$ \\
Error C & 117 & 27.64 \\
\hline Total & 319 & \\
\hline
\end{tabular}

**significant at $1 \%$ probability; *significant at $5 \%$ probability

a Degrees of freedom.

Once significant differences were observed for the effect of genotype $\times$ cutting interaction, methods based on parametric and non-parametric statistics were used for a more detailed analysis of the genotypes' response. The analysis of stability by Yates and Cochran's method, it was found that genotypes 33, 9, 12, 25, 26, 7, 29, 2, 39, and 13 were the most stable and the least productive, whereas genotypes $17,18,36,32$, and 16 were the most productive and unstable (Table 4). This shows that the genotypes with least variance among the cuts were, in general, the least productive and high stability, but these are not interesting for breeding, as they do not respond to improvement in the cuts (ROCHA et al., 20I5).

By Plaisted and Peterson's method, the genotype with the lowest estimator is considered the most stable (CRUZ and CARNEIRO, 20I4). The genotypes 4, 37, 3, I, 30, and 27 demonstrate greater phenotypic stability, i.e., lower contribution to the genotype $\times$ cut interaction, having average dry matter yields of $21.26,19.60,23.14$, 23.95, 18.96, and $24.84 \mathrm{t} \cdot \mathrm{ha}^{-1}$ (Table 4). However, Daher 
TABLE 4 Mean and stability parameters of 40 genotypes of elephant grass.

\begin{tabular}{|c|c|c|c|c|c|c|c|c|c|c|c|c|}
\hline Genotype & Mean & $\mathrm{R}$ & MS & $R$ & $\theta(\%)$ & $\mathrm{R}$ & $\Omega \mathrm{i}(\%)$ & $\mathrm{R}$ & I (\%) & $R$ & $\mathrm{Pi}$ & $R$ \\
\hline I & 23.95 & 16 & 245.99 & 18 & 0.34 & 4 & 0.15 & 4 & 107.57 & 10 & 125.05 & 14 \\
\hline 2 & 16.68 & 37 & $|05.4|$ & 8 & 1.35 & 16 & 1.25 & 16 & 74.5 & 37 & 274.95 & 36 \\
\hline 3 & 23.14 & 17 & 211.02 & 14 & 0.31 & 3 & 0.12 & 3 & 104.36 & 16 & 134.89 & 15 \\
\hline 4 & 21.26 & 23 & 236.97 & 16 & 0.22 & I & 0.01 & I & 94.66 & 19 & 164.7 & 23 \\
\hline 5 & 21.72 & 21 & 276.19 & 22 & 0.76 & 8 & 0.61 & 8 & 93.33 & 21 & 155.33 & 19 \\
\hline 6 & 26.78 & 8 & 482.79 & 35 & 2.99 & 30 & 3.03 & 30 & 114.49 & 6 & 90.01 & 8 \\
\hline 7 & 17.8 & 34 & 86.04 & 6 & 2.89 & 29 & 2.93 & 29 & 78.97 & 33 & 273 & 35 \\
\hline 8 & 20.24 & 25 & 295.19 & 26 & 0.87 & 11 & 0.72 & 11 & 86.3 & 26 & 188.34 & 25 \\
\hline 9 & 12.88 & 40 & 46.26 & 2 & 3.09 & 32 & 3.14 & 32 & 58.2 & 40 & 386.16 & 40 \\
\hline 10 & 24.85 & 9 & 350.89 & 30 & 1.81 & 22 & 1.75 & 22 & 105.74 & 14 & 105.09 & 10 \\
\hline II & 22.69 & 18 & 458.6 & 34 & 4.26 & 35 & 4.42 & 35 & 92.26 & 22 & 158.35 & 20 \\
\hline 12 & 14.33 & 39 & 58.26 & 3 & 3.48 & 33 & 3.57 & 33 & 63.25 & 38 & 345.67 & 39 \\
\hline 13 & I5.27 & 38 & 140.03 & 10 & 1.89 & 23 & 1.84 & 23 & 62.85 & 39 & 308.1 & 38 \\
\hline 14 & 21.75 & 20 & 292.06 & 25 & 1.53 & 19 & 1.44 & 19 & 91.28 & 23 & 164 & 22 \\
\hline 15 & 26.79 & 7 & 434.79 & 32 & 1.57 & 20 & 1.49 & 20 & 113.32 & 7 & 70.14 & 5 \\
\hline 16 & 28.29 & 5 & 488.69 & 37 & 2.79 & 28 & 2.82 & 28 & 118.93 & 4 & 62.6 & 3 \\
\hline 17 & 30.61 & I & 564.33 & 38 & 3.69 & 34 & 3.8 & 34 & 131.04 & 1 & 43.94 & I \\
\hline 18 & 30.37 & 2 & 319.02 & 28 & 10.2 & 39 & 10.9 & 39 & 128.95 & 2 & 89.53 & 7 \\
\hline 19 & 24.26 & 13 & 335.82 & 29 & 0.8 & 10 & 0.65 & 10 & 106.31 & 12 & 113.95 & 11 \\
\hline 20 & 20.9 & 24 & 438.79 & 33 & 2.08 & 24 & 2.04 & 24 & 83.9 & 28 & 168.76 & 24 \\
\hline 21 & 24.36 & 12 & 356.68 & 31 & 1.01 & 13 & 0.88 & 13 & 106.34 & 11 & $1 \mid 4.08$ & 12 \\
\hline 22 & 19.5 & 29 & 231.37 & 15 & 1.26 & 15 & 1.15 & 15 & 79.15 & 32 & 201.12 & 27 \\
\hline 23 & 19.51 & 28 & 259.22 & 19 & 0.78 & 9 & 0.63 & 9 & 83.66 & 29 & 205.23 & 30 \\
\hline 24 & 22.25 & 19 & 312.54 & 27 & 0.98 & 12 & 0.85 & 12 & 96.25 & 18 & 153.55 & 18 \\
\hline 25 & 18.48 & 31 & 71.52 & 4 & 2.53 & 27 & 2.53 & 27 & 84.22 & 27 & 249.03 & 31 \\
\hline 26 & $17.9 \mid$ & 33 & 78.96 & 5 & 3.07 & 31 & 3.12 & 31 & 80.17 & 31 & 262.18 & 34 \\
\hline 27 & 24.85 & 10 & 290.13 & 24 & 0.52 & 6 & 0.35 & 6 & 108.73 & 8 & 102.74 & 9 \\
\hline 28 & 20.19 & 26 & 181.77 & 11 & 1.11 & 14 & 0.99 & 14 & 88.65 & 24 & 203.58 & 28 \\
\hline 29 & 17.66 & 36 & $|03.3|$ & 7 & 2.33 & 25 & 2.32 & 25 & 77 & 35 & 254.88 & 32 \\
\hline 30 & 18.96 & 30 & 237.05 & 17 & 0.45 & 5 & 0.26 & 5 & 77.05 & 34 & 203.75 & 29 \\
\hline 31 & 27.87 & 6 & 971.17 & 40 & 11.3 & 40 & 12.1 & 40 & 106.23 & 13 & 86.69 & 6 \\
\hline 32 & 28.96 & 4 & 487.57 & 36 & 2.45 & 26 & 2.45 & 26 & 121.76 & 3 & 45.28 & 2 \\
\hline 33 & 17.75 & 35 & 42.86 & 1 & 5.7 & 37 & 5.98 & 37 & 81.27 & 30 & 287.21 & 37 \\
\hline 34 & 24.17 & 14 & 190.55 & 12 & 1.37 & 17 & 1.27 & 17 & 107.92 & 9 & $|37.9|$ & 16 \\
\hline 35 & 24.5 & 11 & 284.7 & 23 & 1.6 & 21 & 1.52 & 21 & 103.85 & 17 & 115.98 & 13 \\
\hline 36 & 29.49 & 3 & 743.17 & 39 & 9.61 & 38 & 10.24 & 38 & $116.9 \mid$ & 5 & 69.05 & 4 \\
\hline 37 & & 27 & 203.92 & 13 & 0.24 & 2 & 0.04 & 2 & 86.89 & 25 & 198.49 & 26 \\
\hline 38 & 21.55 & 22 & 266.02 & 20 & 0.74 & 7 & 0.58 & 7 & 93.4 & 20 & 161.52 & 21 \\
\hline 39 & 17.93 & 32 & 107.9 & 9 & 4.56 & 36 & 4.75 & 36 & 76.18 & 36 & 261.95 & 33 \\
\hline 40 & 23.96 & 15 & 275.84 & 21 & 1.43 & 18 & 1.34 & 18 & 104.69 & 15 & 138.63 & 17 \\
\hline
\end{tabular}

Stability parameters: Yates and Cochran's square mean $(M S)$, Wricke's ecovalence $(\theta)$, Plaisted and Peterson's stability $(\omega i)$, Annichiarico's genotypic confidence index (I), Lin and Binns's stability index ( $P i)$. R: Ranking.

et al. (2003) obtained estimates by Plaisted and Peterson's methods of forage production of elephant grass and observed that there was no concordance between stability and productivity; in other words, the most productive genotypes were not necessarily the most stable.

Wricke's method considers the genotype with the lowest $\omega_{i(\%)}$ estimator as the most stable; this and Plaisted and Peterson's method are similars, as both use the decomposition of the sum of squares of the genotype $\times$ cuts interaction in the derivation of their stability parameters (Cruz and Carneiro, 20l4). Therefore, the obtained conclusions were the same for both stability methods.

In the method proposed by Annicchiarico, stability is measured by the superiority of the genotype in relation to the mean of each cuts. The method is based upon the estimation of a confidence index of a given genotype showing a relatively superior behavior (Table 4). Based on the confidence index, genotypes 17, 18, 32, $16,36,15$, and 6 stood out as the most productive and showed the greatest confidence indices always superior to $110 \%$. This result indicates that on the average of cuts, these genotypes should present, in the worst case scenario, biomass productivities 10\% higher than the mean, i.e., there is a lower risk of adopting these materials (DEHAAN et al., 20I0).

The methodology proposed by Lin and Binns allows for quantifying how close a cultivar is to ideal performance, which is understood as a cultivar has highest production in all studied environments (CRUZ 
and CARNEIRO, 20I4). By the ranking of genotypes, it could be observed that their productivity was overall inversely related to their $P_{i}$ estimate (Table 4); genotypes that displayed high stability, such as I7, 32, I6, 36, I5, 31 , and 18, with production above the means of each environment, contributed least to the interaction as compared with the maximum. In Cunha et al. (20I3), by Lin and Binns' method, the genotypes of elephant grass showed low $P_{i}$ values, which ranked them as materials with extensive environmental adaptation and as the most productive, because the deviation in relation to the maximum productivity of each environment is reduced as $P_{i}$ is decreased.

Kang and Phan's ranking, associated with the Yates and Cochran method, presented genotypes 34, 18 , 3 , I, and 27 among the most stable (Table 5). Overall, the most productive genotypes rose to better positions after Kang and Phan's weighting. Genotype 18, which has the 2nd best productivity - $30.65 \mathrm{t} \cdot \mathrm{ha}^{-1}$ - was considered the most unstable according to Yates and Cochran's method, and after weighting, it moved into $2^{\text {nd }}$ place.

Because Plaisted and Peterson's and Wricke's method obtained perfect correlation, the application of Kang and Phan's procedure resulted in a same ranking of the genotypes. The five best genotypes, according to Plaisted and Peterson's and Wricke's method, before Kang and Phan's weighting, were 4, 37, 3, I, and 27, which were ranked $23^{\text {rd }}, 27^{\text {th }}, 17^{\text {th }}, 16^{\text {th }}$ and $30^{\text {th }}$, respectively, for productivity. After Kang and Phan's weighting, genotypes $27,3,1,19$, and 4 stood out, being ranked $2^{\text {nd }}, 3^{\text {rd }}, 4^{\text {th }}$ and $5^{\text {th }}$ place, respectively. In Daher et al. (2003), the same

TABLE 5 Kang and Phan's associated with stability method of 40 genotypes of elephant grass.

\begin{tabular}{|c|c|c|c|c|c|c|c|c|c|c|c|c|}
\hline Genotype & Mean & $\mathrm{R}$ & $\mathrm{K}+\mathrm{YC}$ & $\mathrm{R}$ & $\mathrm{K}+\mathrm{PP}$ & $\mathrm{R}$ & $\mathrm{K}+\mathrm{W}$ & $\mathrm{R}$ & $\mathrm{K}+\mathrm{An}$ & $\mathrm{R}$ & $K+L B$ & $\mathrm{R}$ \\
\hline 1 & 23.95 & 16 & 34 & 4 & 16 & 3 & 16 & 3 & 2 & 14 & 2 & 14 \\
\hline 2 & 16.68 & 37 & 45 & 31 & 20 & 30 & 20 & 30 & 4 & 37 & 6 & 37 \\
\hline 3 & 23.14 & 17 & 31 & 3 & 20 & 2 & 20 & 2 & 7 & 17 & 7 & 16 \\
\hline 4 & 21.26 & 23 & 39 & 12 & 23 & 5 & 23 & 5 & 8 & 20 & 8 & 23 \\
\hline 5 & 21.72 & 21 & 43 & 27 & 24 & 10 & 24 & 10 & 9 & 22 & 9 & 20 \\
\hline 6 & 26.78 & 8 & 43 & 29 & 25 & 22 & 25 & 22 & 14 & 6 & 12 & 8 \\
\hline 7 & 17.80 & 34 & 40 & 16 & 27 & 35 & 27 & 35 & 14 & 34 & 12 & 35 \\
\hline 8 & 20.24 & 25 & 51 & 38 & 29 & 20 & 29 & 20 & 18 & 25 & 16 & 25 \\
\hline 9 & 12.88 & 40 & 42 & 20 & 29 & 38 & 29 & 38 & 19 & 40 & 19 & 40 \\
\hline 10 & 24.85 & 9 & 39 & 13 & 29 & 14 & 29 & 14 & 23 & 12 & 19 & 10 \\
\hline II & 22.69 & 18 & 52 & 39 & 30 & 31 & 30 & 31 & 23 & 19 & 24 & 19 \\
\hline 12 & 14.33 & 39 & 42 & 21 & 31 & 39 & 31 & 39 & 23 & 38 & 24 & 39 \\
\hline 13 & 15.27 & 38 & 48 & 37 & 31 & 33 & 31 & 33 & 25 & 39 & 24 & 38 \\
\hline 14 & 21.75 & 20 & 45 & 32 & 31 & 23 & 31 & 23 & 26 & 23 & 30 & 21 \\
\hline 15 & 26.79 & 7 & 39 & 14 & 32 & 7 & 32 & 7 & 28 & 7 & 30 & 6 \\
\hline 16 & 28.29 & 5 & 42 & 24 & 33 & 17 & 33 & 17 & 30 & 5 & 32 & 4 \\
\hline 17 & 30.61 & I & 39 & 15 & 33 & 19 & 33 & 19 & 33 & I & 32 & I \\
\hline 18 & 30.37 & 2 & 30 & 2 & 35 & 26 & 35 & 26 & 37 & 2 & 37 & 5 \\
\hline 19 & 24.26 & 13 & 42 & 23 & 35 & 4 & 35 & 4 & 40 & 13 & 38 & II \\
\hline 20 & 20.90 & 24 & 57 & 40 & 36 & 29 & 36 & 29 & 42 & 26 & 40 & 24 \\
\hline 21 & 24.36 & 12 & 43 & 28 & 37 & 6 & 37 & 6 & 42 & 11 & 42 & 12 \\
\hline 22 & 19.50 & 29 & 44 & 30 & 38 & 27 & 38 & 27 & 42 & 30 & 43 & 29 \\
\hline 23 & 19.51 & 28 & 47 & 36 & 39 & 21 & 39 & 21 & 43 & 28 & 46 & 28 \\
\hline 24 & 22.25 & 19 & 46 & 33 & 40 & 12 & 40 & 12 & 50 & 18 & 48 & 18 \\
\hline 25 & 18.48 & 31 & 35 & 7 & 41 & 32 & 41 & 32 & 51 & 29 & 50 & 31 \\
\hline 26 & 17.91 & 33 & 38 & II & 41 & 36 & 41 & 36 & 52 & 31 & 53 & 33 \\
\hline 27 & 24.85 & 10 & 34 & 6 & 44 & I & 44 & I & 52 & 8 & 54 & 9 \\
\hline 28 & 20.19 & 26 & 37 & 10 & 46 & 24 & 46 & 24 & 57 & 24 & 56 & 27 \\
\hline 29 & 17.66 & 36 & 43 & 26 & 48 & 34 & 48 & 34 & 58 & 36 & 58 & 34 \\
\hline 30 & 18.96 & 30 & 47 & 35 & 53 & 18 & 53 & 18 & 61 & 32 & 59 & 30 \\
\hline 31 & 27.87 & 6 & 46 & 34 & 53 & 28 & 53 & 28 & 64 & 9 & 62 & 7 \\
\hline 32 & 28.96 & 4 & 40 & 18 & 58 & II & 58 & II & 64 & 3 & 65 & 2 \\
\hline 33 & 17.75 & 35 & 36 & 8 & 61 & 40 & 61 & 40 & 65 & 33 & 67 & 36 \\
\hline 34 & 24.17 & 14 & 26 & I & 61 & 13 & 61 & 13 & 67 & 10 & 68 & 15 \\
\hline 35 & 24.50 & II & 34 & 5 & 63 & 15 & 63 & 15 & 68 & 15 & 69 & 13 \\
\hline 36 & 29.49 & 3 & 42 & 25 & 64 & 25 & 64 & 25 & 7I & 4 & 72 & 3 \\
\hline 37 & 19.60 & 27 & 40 & 17 & 68 & 8 & 68 & 8 & 74 & 27 & 73 & 26 \\
\hline 38 & 21.55 & 22 & 42 & 22 & 72 & 9 & 72 & 9 & 77 & 21 & 76 & 22 \\
\hline $\begin{array}{l}39 \\
40 \\
\end{array}$ & $\begin{array}{l}17.93 \\
23.96\end{array}$ & $\begin{array}{l}32 \\
15\end{array}$ & $\begin{array}{l}41 \\
36 \\
\end{array}$ & $\begin{array}{c}19 \\
9\end{array}$ & $\begin{array}{l}72 \\
72\end{array}$ & $\begin{array}{l}37 \\
16\end{array}$ & $\begin{array}{l}72 \\
72 \\
\end{array}$ & $\begin{array}{l}37 \\
16\end{array}$ & $\begin{array}{l}77 \\
80\end{array}$ & $\begin{array}{l}35 \\
16\end{array}$ & $\begin{array}{l}78 \\
80\end{array}$ & $\begin{array}{l}32 \\
17 \\
\end{array}$ \\
\hline
\end{tabular}

K: Kang and Phan, Yates and Cochran (YC), Plaisted and Peterson (PP), Wricke (W), Annichiarico (An), Lin and Binns (LB), R: ranking 
correlation was observed, wherein the results obtained from estimates of Kang's stability parameter ratified the good performance of the 17 studied genotypes.

Genotypes 17, 18, 32, 36, 16, 6, and 15 stood out as highly promising by Lin and Binns' method. However, the genotypes indicated by Kang Phan's associated with Lin and Binns' method were 17, 32, 36, 16, 18, 15, and 31 , keeping the first five that showed high stability both in favorable and unfavorable environments (Table 5).

In Annicchiarico's method, the genotypes with the highest confidence index were those with highest stability. Associated with Kang and Phan's, this method indicated genotypes 17, 18, 36, 16, 6, and 15 as the most stable and productive. Thus, both methodologies presented good concordance in identifying the cultivars with greatest stability (DEHAAN et al., 20I0; ROCHA et al., 20I5).

The methods showed a positive correlation with the mean at the significance level of $1 \%$, indicating that one of them is sufficient for the selection of stable genotypes, except Plaisted and Peterson's and Wricke's, which were not significant (Table 6). Scapim et al. (2010) selected best cultivars of popcorn based on stability and adaptability methods and found a significant and positive correlation between Wricke's method and the production mean. Yates and Cochran's method showed a non-significant correlation with Plaisted and Peterson's and Wricke's, and negative and significant correlations with the others; its correlation with the mean, for instance, was $-0.865(p<0.01)$, indicating that individuals with lower variation throughout the cuts have lower production means.

According to Spearman's coefficient, the methods of Plaisted and Peterson and Wricke were perfectly correlated with each other $(\rho=I)$, and so they have similar correlations with the other methods. This concordance between the estimates of parameters of these two stability methods reveals that the indication of cultivars is the same irrespective of the method, and that the use of both is necessary. Lin and Binns' method had high positive correlations with the means of the genotypes (0.989) and with Annicchiarico's (0.962), and the results obtained by Annicchiarico's method were very similar to those obtained by the model of Lin and Binns. Contrary to Cunha et al., (20I3), who evaluated eight elephant-grass genotypes, Spearman's correlation between Lin and Binns' method and the mean was negative, and Annicchiarico's method had a correlation of 0.967 with the productivity mean.

With the use of Kang and Phan's methodology associated with Yates and Cochran's there was no significant correlation with the mean, Plaisted and Peterson, Wricke and Lin and Binns. Positive correlation was only found with Annicchiarico's method ( $\rho=0.338$ ). Kang and Phan's weighting associated with Plaisted and Peterson's showed to be correlated with the mean productivity and with all methods $(P<0.0 I)$, except for Yates and Cochran and Kang and Phan's associated with Yates and Cochran's. The same can be concluded for Kang and Phan's method associated with Wricke's, since both had a correlation coefficient of I. Kang and Phan's method associated with Annicchiarico and Lin and Binns presented a significant correlation with Annicchiarico, Lin and Binns, Kang and Phan associated with Plaisted and Peterson and Wricke. The correlation between Annicchiarico's method associated with Kang and Phan's with the Plaisted and Peterson (-0.044), Wricke $(-0.044)$ and Kang and Phan associated with Yates and Cochran (0.606) were not significant. The results of the methodology of Lin and Binns and Annicchiarico were similar, which is in agreement with the results obtained by Rocha et al., (2015) regarding the similarity in the recommendation of the genotypes by these methodologies.

\section{CONCLUSIONS}

The present study reported stability analysis indicated that the parametric methods to give emphasis to inferior genotypes in productivity values. On the other hand, non-parametric methods (LIN and BINNS and Annicchiarico), which recommend deviations from the maximum means, to identified superior

TABLE 6 Spearman's correlations among the stability parameters of the different methods utilized in 40 genotypes of elephant grass.

\begin{tabular}{|c|c|c|c|c|c|c|c|c|c|c|}
\hline & YC & PP & $\mathrm{Wi}$ & I & $\mathrm{Pi}$ & $\mathrm{K}+\mathrm{YC}$ & $K+P P$ & $K+\omega i$ & $\mathrm{~K}+\mathrm{I}$ & $\mathrm{K}+\mathrm{Pi}$ \\
\hline Mean & $-0.865^{\text {*** }}$ & -0.076 & -0.076 & $0.967 * *$ & 0.989*** & 0.209 & 0.579*** & $0.579 * *$ & 0.988** & $0.995^{* *}$ \\
\hline YC & - & 0.103 & 0.103 & $-0.765^{* *}$ & $-0.870^{* * *}$ & 0.285 & $-0.432^{* *}$ & $-0.432 * *$ & $-0.82 I^{*} * *$ & -0.869 *** \\
\hline PP & - & - & 1.000 & -0.007 & -0.017 & 0.030 & $0.736^{* * *}$ & $0.736 * *$ & -0.044 & -0.039 \\
\hline Wi & - & - & - & -0.007 & -0.017 & 0.030 & 0.736 *** & $0.736 * *$ & -0.044 & -0.039 \\
\hline 1 & - & - & - & - & $0.962 * *$ & $0.338 *$ & $0.635^{* * *}$ & $0.635 * *$ & $0.991 * *$ & 0.97 I**⿻丷木 \\
\hline $\mathrm{Pi}$ & - & - & - & - & - & 0.179 & $0.629 * *$ & $0.629 * *$ & $0.980 * *$ & $0.997 *$ ** \\
\hline $\mathrm{K}+\mathrm{YC}$ & - & - & - & - & - & - & 0.248 & 0.248 & 0.269 & 0.194 \\
\hline $\mathrm{K}+\mathrm{PP}$ & - & - & - & - & - & - & - & 1.000 & $0.606 * *$ & $0.614^{*} *$ \\
\hline $\mathrm{K}+\omega \mathrm{i}$ & - & - & - & - & - & - & - & - & $0.606 * *$ & $0.614 * *$ \\
\hline $\mathrm{K}+\mathrm{I}$ & - & - & - & - & - & - & - & - & - & $0.988^{* * *}$ \\
\hline $\mathrm{K}+\mathrm{Pi}$ & - & - & - & - & - & - & & - & - & - \\
\hline
\end{tabular}

** significant at $1 \%$ probability; *significant at $5 \%$ probability. 
genotypes. The Genotypes Mercker Pinda-México, Mercker 86-México, Guaçu/IZ, Mercker Pinda, P-24IPiracicaba, and Cubano Pinda were stable responsive to favorable environment. Hence, there genotypes may be exploited in future breeding programmes for biomass production in order to improve productivity of upland elephant grass over environment.

\section{REFERENCES}

ANDERSON W.F.; DIEN B.S.; BRANDON S.K.; PETERSON J.D. Assessment of Bermuda grass and bunch grasses as feedstocks for conversion to ethanol. Applied Biochemistry Biotechnology, v. I45, p. I3-21,2008.

AZEVEDO, A.L.S.; COSTA, P.P.; MACHADO, J.C.; MACHADO, M.A.; PEREIRA, A.V.; LEDO, F.J. da S. Cross Species Amplification of Pennisetum glaucum Microsatellite Markers in Pennisetum purpureum and Genetic Diversity of Napier Grass Accessions. Crop Science, v.52, p. 1776-1785,20I2.

BOSE, L. K.; JAMBHULKAR, N. N.; PANDE, K.; SINGH, O. N. Use of AMMI and other stability statistics in the simultaneous selection of rice genotypes for yield and stability under direct-seeded conditions. Chilean Journal of Agricultural Research, v. 74,p. 3-9, 2014.

CASTILLO, D.; MATUS, I.; DEL POZO, A.; MADARIAGA ,R.; MELLADO, M. Adaptability and genotype $\times$ environment interaction of spring wheat cultivars in Chile using regression analysis, AMMI, and SREG. Chilean Journal of Agricultural Research ,v. 72,p. 167-I74, 2012.

CRUZ, C.D.GENES: a software package for analysis in experimental statistics and quantitative genetics. Acta Scientiarum. Agronomy, v.35, p.27I-276, 2013.

CRUZ, C.D.; CARNEIRO, P.C.S. Modelos Biométricos Aplicados ao Melhoramento Genético. Viçosa, Brazil: Viçosa University Press, 2014,564p.

CUNHA, M. V. da; LIRA, M. DE A.; SANTOS, M. V. F. dos; DUBEUX JÚNIOR, J. C. B;, DE MELLO, A. C. L.; FREITAS, E. V. Adaptabilidade e estabilidade da produção de forragem por meio de diferentes metodologias na seleção de clones de Pennisetum spp. Revista Brasileira de Ciências Agrárias, v. 8, p.68I-686, 2013.

DAHER, R.F.; PEREIRA, M. G.; AMARAL JR, A. T. A.; PEREIRA, V.; LÉDO, F. J. S.; DAROS, M. Estabilidade da produção forrageira em clones de capim-elefante (Pennisetum purpureum Schum.). Ciência Agrotecnologia, v. 27 ,p. 788-797,2003.

DAHER, R. F.; SOUZA, L.B.; GRAVINA, G.A.; MACHADO, J.C.; RAMOS, H.C.C.; SILVA, V.Q.R.; MENEZES, B.R.S.; SCHNEIDER, L.S.A.; OLIVEIRA, M.L.F.; GOTTARDO, R.D. Use of elephant grass for energy production in Campos dos Goytacazes-RJ, Brazil. Genetics and Molecular Research, v.13, p.10898-10908, 2014.
DEHAAN, L. R.; WEISBERG, S.; TILMAN, D.; FORNARA, D. Agricultural and biofuel implications of a species diversity experiment with native perennial grassland plants. Agriculture, Ecosystems and Environment,v. I37, p.3338, 2010.

ESCOBAR, M.; BERTI M.; MATUS I.; TAPI M; JOHNSON, B. Genotype $\times$ environment interaction in canola (Brassica Napus I.) seed yield in Chile. Chilean Journal of Agricultural Research,v. 7I, p.I75-186, 201 I.

JAKOB, K.; ZHOU F.; PATERSON, A.H. Genetic improvement of C4 grasses as cellulosic biofuel feedstocks. In Vitro Cellular e Developmental Biology-Plant, v. 45, p. 29I-305, 2009.

KALT, G. ; KRANZ ,L. L. Assessing the economic efficiency of bioenergy technologies in climate mitigation and fossil fuel replacement in Austria using a techno-economic approach. Applied Energy, v. 88, p.3665-3684, 201 I.

LEE, M.K.; TSAI, W.T.; TSAI, Y.L.; LIN S.H. Pyrolysis of napier grass in an induction-heating reactor. Journal of Analytical and Applied Pyrolysis. v. 88, p. I I0-I 16, 2010.

MENEZES B.R.; DAHER R.F.; GRAVINA G.D.A.; PEREIRA A.V.; SOUSA L.B.; RODRIGUES E. V.; SILVA, V.B.; GOTTARDO, R.D.;SCHNEIDER L.S.A. ; NOVO, A.A Estimates of heterosis parameters in elephant grass (Pennisetum purpureum Schumach.) for bioenergy production. Chilean Journal of Agricultural Research, v.75, p. 395-40I, 2015.

MONTI, A.; ZATTA, A. Root distribution and soil moisture retrieval in perennial and annual energy crops in Northern Italy. Agriculture, Ecosystems and Environment, v.132,p. 252, 2009.

NASCIMENTO, M.; NASCIMENTO, A. C. C.; CIRILLO, M. Â.; FERREIRA, A.; PETERNELLI, L. A.; DE PAULA, R. F. Association between responses obtained using adaptability and stability methods in alfalfa. Semina: Ciências Agrárias, v. 34, p. 2545-2554, 2013.

OLIVEIR, É.; DAHER, R. F.; PONCIANO, N. J.; DE AMARAL GRAVINA, G.; de ALMEIDA SANT'ANA ,J. A.; GOTTARDO, R. D.; SILVA, V.B.; ROCHA, A.S. Variation of Morpho-Agronomic and Biomass Quality Traits in Elephant Grass for Energy Purposes According to Nitrogen Levels. American Journal of Plant Sciences, v. I I, p. I685, 2015.

OLIVEIRA, A. V. de; DAHER, R. F.; MENEZES, B. R. DA S.; GRAVINA, G. DE A.; SOUSA, L. B. DE ;GONÇALVES, A. C. DA S. ; OLIVEIRA, M. L. F. Avaliação do desenvolvimento de 73 genótipos de capim-elefante em Campos dos Goytacazes - RJ. Boletim Indústria animal, v.70, p. I I9-131, 2013.

OLIVEIRA, M. L. F; DAHER, R. F;; GRAVINA, G. A.; SILVA, V.B.; VIANA, A.P.; RODRIGUES, E.V.; SHIMOYA A.; AMARAL JÚNIOR A.T.; MENEZES, B.R.S. ;ROCHA, A.S. Pre-breeding of elephant grass for energy purposes and biomass analysis in Campos dos Goytacazes-RJ, Brazil. African Journal Agricultural Research, v. 9, p. 2743-2758, 2014. 
ROCHA, A.S.; DAHER, R.F; GRAVINA, G.A.; PEREIR,A A.V.; RODRIGUES, E.V.; VIANA, A.P.; OLIVEIRA, E.S. Comparison of stability methods in elephant-grass genotypes for energy purposes. African Journal of Agricultural Research, v. 10, p. 4283-4294, 2015.

ROSSI, D.A.; MENEZES, B.R.S.; DAHER, R.F; GRAVINA, G.A.; LIMA, R.S.N.; LÉDO, F.J.S.; GOTTARDO, R.D.; CAMPOSTRINI, E. ; SOUZA, C. L.M. Canonical correlations in elephant grass for energy purposes. African Journal Biotechnology,v. 36, p. 3666-367I, 2014.

SANTOS M. M. P.; DAHER, R. F; PONCIANO, N. J.; DE AMARAL GRAVINA, G.; PEREIRA, A.V.; SANT'ANA, J. A.; SANTOS, C. L. Características produtivas de capimelefante sob doses de fósforo e nitrogênio para fins energéticos. Científica, v. 42, p.354-365,20I4.

SANTO, M. M. P.; DAHER, R. F.; PONCIANO, N. J.; GRAVINA ,G. A.; PEREIRA, A. V.; SANTOS, C. L. Respostas do capimelefante sob doses de adubação azotada de cobertura para fins energéticos. Revista de Ciências Agrárias, v. 37, p. I00-108, 2014.
SCAPIM, C. A.; PACHECO, C. A. P.; AMARAL JÚNIOR, A. T.; VIEIRA, A.; PINTO, R. J. B.; CONRADO, T. V. Correlations between the stability and adaptability statistics of popcorn cultivars. Euphytica, I74, 209-218, 2010.

SCHOLL, A. L.; MENEGOL, D.; PITARELO, A.P.; FONTANA, R.C.; ZANDONA FILHO, A.; RAMOS, L.P.; DILLON, A.J.P.; CAMASSOLA M. Elephant grass (Pennisetum purpureum Schum.) pretreated via steam explosion as a carbon source for cellulases and xylanases in submerged cultivation. Industrial Crops and Products ,v. 70, p. 280-29I, 2015.

SINGH, S. A.; SINGH, V.V.; CHOUDHARY A. D. GenotypeX environment interaction and yield stability analysis in multienvironment. Tropical and Subtropical Agroecosystems, v. 17, n.3, 2014.

SOMERVILLE, C.; YOUNGS H.; TAYLO C.; DAVIS S.C.; LONGS, S.P. Feedstocks for lignocellulosic biofuels. Science,v. 329,p. 790-792, 2010.

STEEL, R.G.D.; TORRIE, J.H.; DICKEY, D.A.Principles and procedures of statistics: A biometrical approach. New York, USA: McGraw-Hill Press, 1996, 230p. 